This document is the accepted manuscript version of the following article:

Zhu, J., Sushkevich, V. L., Knorpp, A. J., Newton, M. A., Mizuno, S. C. M., Wakihara, T., ... van Bokhoven, J. A. (2020). Cu-

erionite zeolite achieves high yield in direct oxidation of methane to methanol by isothermal chemical looping. Chemistry of Materials. https://doi.org/10.1021/acs.chemmater.9b04223

\title{
Cu-Erionite Zeolite Achieves High Yield in Direct Oxidation of Methane to Methanol by Isothermal Chemical Looping
}

\author{
Jie Zhu,${ }^{\dagger \S}$ Vitaly L. Sushkevich, ${ }^{\star}$ Amy J. Knorpp,${ }^{\dagger}$ Mark A. Newton, ${ }^{\dagger}$ Stefanie C. M. Mizuno, ${ }^{\dagger}$ Toru \\ Wakihara, ${ }^{\S}$ Tatsuya Okubo, ${ }^{\S}$ Zhendong Liu ${ }^{*}$ and Jeroen A. van Bokhoven ${ }^{* \dagger \dagger}$ \\ †nstitute for Chemical and Bioengineering, ETH Zurich, Vladimir-Prelog-Weg 1, 8093 Zurich, Switzerland \\ Laboratory for Catalysis and Sustainable Chemistry, Paul Scherrer Institute, 5232 Villigen, Switzerland \\ ${ }^{\S}$ Department of Chemical System Engineering, The University of Tokyo, 7-3-1, Hongo, Bunkyo-ku, 113-8656 Tokyo, Japan
}

\begin{abstract}
We herein report that a copper-ion-exchanged erionite zeolite (Cu-ERI) exhibited a methanol yield as high as 147 $\mu \mathrm{mol} / \mathrm{g}$-zeolite, equaling $0.224 \mu \mathrm{mol} / \mu \mathrm{mol}-\mathrm{Cu}$, in the direct oxidation of methane to methanol. Moreover, this high methanol yield was achieved using an isothermal chemical looping with both oxygen activation and reaction with methane carried out at $300^{\circ} \mathrm{C}$, in contrast to the conventional stepwise protocol where activation is performed at high temperature $\left(450{ }^{\circ} \mathrm{C}\right.$ and above) and the methane reaction at lower temperature (typically $200^{\circ} \mathrm{C}$ ). Under isobaric condition ( $1 \mathrm{bar}$ ), the $\mathrm{Cu}$-ERI still gave a high yield of $80 \mu \mathrm{mol} / \mathrm{g}$ zeolite after a single aqueous extraction of the methanol. Such improvements indicate that high yields can be obtained over $\mathrm{Cu}$-ERI in the direct conversion of methane to methanol by a chemical looping without any temperature or pressure swing.
\end{abstract}

\section{INTRODUCTION}

Methane, the major component of natural gas, is both abundant and cheap and is thus considered to hold promise to replace other fossil fuels (such as oil and coal) as a source of energy and chemicals. ${ }^{[1-3]}$ The direct conversion of methane to methanol is a highly desirable route for efficient utilization of methane, but, it has remained a longstanding challenge in hydrocarbon chemistry. ${ }^{[4-6]}$ The chemical properties of methane and methanol make selective oxidation of methane to methanol extremely difficult. ${ }^{[7,8]}$ The higher chemical reactivity of methanol, compared to that of methane, favors deep oxidation to unwanted products such as $\mathrm{CO}$ and $\mathrm{CO}_{2}$, which complicates this process. ${ }^{[9-11]}$

Numerous researchers have explored the stepwise conversion of methane to methanol using copper-exchanged materials. ${ }^{[12-40]}$ The most-studied zeolites for direct oxidation of methane to methanol are mordenite ${ }^{[16-20,22-25]}$ and ZSM-5, ${ }^{[12,13,15,27-29]}$ and, since 2005, ${ }^{[13]}$ the overall methanol yields have increased significantly. Based on these findings, a wide range of zeolites, such as $\mathrm{BEA}^{[31]}, \mathrm{FAU}^{[32]}$ and $\mathrm{MAZ}^{[35]}$, and non-crystalline oxides, such as silica ${ }^{[36,37]}$ and alumina,${ }^{[38]}$ have been found to yield methanol directly from methane when doped with copper. Very recently, it was reported that, $\mathrm{Cu}-\mathrm{CHA}^{[33]}$, a small-pore zeolite, exhibited methanol yields up to $125 \mu \mathrm{mol} / \mathrm{g}$-zeolite after four reactive cycles. The reactivity of the $\mathrm{Cu}-\mathrm{CHA}$ system was related to confinement effects in the 8-membered ring (8MR) of CHA, which stabilizes highly dispersed copper-oxo active species and which then may facilitate the conversion of methane to methanol. ${ }^{[39]}$ Earlier work by Lobo et al., which focused on a series of copper-containing small-pore zeolites for this reaction, also suggested that small-pore zeolites are promising materials for methane oxidation. ${ }^{[34]}$

In the conventional step-wise reaction protocol, copper-based zeolites are activated with oxygen at temperatures above $450{ }^{\circ} \mathrm{C}$ followed by the reaction with methane at a considerably lower temperature (about $200{ }^{\circ} \mathrm{C}$ ). Methanol is subsequently extracted using water at ambient temperature, or by steaming at an elevated temperature (Figure 1(a) and Figure S1). The repeated heating and cooling cycles involved in this conventional approach are significant barriers to the development of a practical process. Tomkins et $a l$. reported an isothermal process over $\mathrm{Cu}-\mathrm{MOR}$ zeolite, where the temperature for both oxygen activation and methane reaction was constant. However, this comes at a price. Only half the amount of methanol was produced in that isothermal procedure compared with the amount achieved in the conventional procedure, even when a high methane pressure of 36 bar was applied. ${ }^{[40]}$ An isothermal conversion of methane to methanol without pressure swings was demonstrated recently for $\mathrm{Cu}$-Faujasite ( $\mathrm{Cu}-\mathrm{FAU})$, emphasizing the importance of making temperatures of oxygen activation and methane reaction equal. ${ }^{[32]}$ Here, we report that copper-ion-exchanged erionite zeolite (Cu-ERI), a small-pore zeolite, can lead to a high methanol yield in the direct oxidation of methane to methanol using an isothermal procedure (Figure 1(b)). Our results demonstrate that oxygen activation at high temperature (above $450{ }^{\circ} \mathrm{C}$ ) is not a prerequisite for achieving a high methanol yield. With an optimal Cu/Al ratio of 0.3 , a methanol yield of $147 \mu \mathrm{mol} / \mathrm{g}$ zeolite can be achieved within the isothermal protocol. This is equivalent to the yield obtained under conventional conditions with high-temperature activation.

\section{EXPERIMENTAL SECTION}

Materials. The following materials were used as received: aluminum sec-butoxide $\left(\mathrm{Al}\left[\mathrm{OCH}\left(\mathrm{CH}_{3}\right) \mathrm{C}_{2} \mathrm{H}_{5}\right]_{3}, 97 \%\right.$, Aldrich) as an aluminum source, colloidal silica (LUDOX® AS-40, 40 wt.\% suspension) as a silica source, potassium hydroxide solution (Wako Pure Chemical Industries, Ltd., $30 \mathrm{wt} \%$ ) as an alkali source, hexamethonium bromide (Tokyo Chemical Industry, Ltd., >98 wt\%) as the crystallization organic structure-directing agent. ERI seed crystals were synthesized according to the charge density mismatch (CDM) method.

Zeolite Synthesis. ERI zeolite was prepared, but not according to the $\mathrm{CDM}$ approach, with a reactant mixture comprising 1.63 $\mathrm{RBr}_{2} / 7.8 \mathrm{KOH} / 0.8 \mathrm{Al}_{2} \mathrm{O}_{3} / 16 \mathrm{SiO}_{2} / 258 \mathrm{H}_{2} \mathrm{O}$, where TPAOH and 
$\mathrm{RBr}_{2}$ represent tetrapropylammonium and hexamethonium bromide, respectively. First, aluminum sec-butoxide was dissolved in potassium hydroxide solution, followed by the dropwise addition of a solution containing hexamethonium bromide dissolved in deionized water. Colloidal silica was then slowly added to form an aluminosilicate reactant. The reactant mixture was homogenized for $2 \mathrm{~h}$ and aged for $24 \mathrm{~h}$ in an oven at $95{ }^{\circ} \mathrm{C}$. After aging, $10 \mathrm{wt} \%$ ERI seed crystals, synthesized according to the recipe in Ref. 41, were added to the reactant mixture and stirred for $10 \mathrm{~min}$. The resulting reactant was fed into a sealed pipe reactor and heated at $210^{\circ} \mathrm{C}$ for $2 \mathrm{~h}$. The solid products were recovered by centrifugation, washed with de-ionized water and dried at $80^{\circ} \mathrm{C}$

Preparation of Cu-ERI Materials with Different Copper Loadings. The synthesized ERI zeolite was calcined at $550{ }^{\circ} \mathrm{C}$ for $8 \mathrm{~h}$ to remove the organic structure-directing molecules occluded in the zeolite. The calcined ERI zeolite was then ion-exchanged twice with $1 \mathrm{M} \mathrm{NH}_{4} \mathrm{NO}_{3}$ solution at $90^{\circ} \mathrm{C}$ for $5 \mathrm{~h}$. $\mathrm{Cu}$-ERI material was prepared by liquid ion exchange of $\mathrm{NH}_{4}$-ERI with $\left(\mathrm{CH}_{3} \mathrm{COO}\right)_{2} \mathrm{Cu}$ solution at $90{ }^{\circ} \mathrm{C}$ for $30 \mathrm{~min}$. After centrifugation and drying in an oven, the obtained $\mathrm{Cu}$-ERI zeolite was calcined at $550{ }^{\circ} \mathrm{C}$ for $3 \mathrm{~h}$. Cu-ERI materials with different copper loadings were readily controlled by varying the concentration of $\left(\mathrm{CH}_{3} \mathrm{COO}\right)_{2} \mathrm{Cu}$ aqueous solutions.

Characterizations. The crystallinity of all the solid products was identified with a Panalytical X'Pert Pro MPD instrument $(\lambda=$ $0.15406 \mathrm{~nm}, 40 \mathrm{kV}, 40 \mathrm{~mA}$ ) at a scan rate of $4 \% \mathrm{~min}$. The crystallinity of the solid product was calculated based on the area of the peaks ranging from $20^{\circ}$ to $30^{\circ}$. The crystal size and morphology of the solid products were confirmed with scanning electron microscopy (Zeiss Gemini 1530) at an acceleration voltage of $5 \mathrm{keV}$.

Elemental analysis of the products was carried out using a SpectraAA 220FS atomic absorption spectrometer. Fifteen milligrams of $\mathrm{Cu}$-ERI were dissolved with $2 \mathrm{ml}$ hydrofluoric acid and $3 \mathrm{ml}$ nitric acid and then diluted to $50 \mathrm{ml}$ with deionized water. Nitrogen adsorption-desorption measurements were performed to evaluate the micropore volume of the zeolite products using a Quantachrome Autosorb-iQ at $-196^{\circ} \mathrm{C}$. Prior to the measurements, all samples were preheated at $325^{\circ} \mathrm{C}$ for $6 \mathrm{~h}$ under vacuum.

FTIR spectroscopy was performed on a Thermo Nicolet iS50 spectrometer with a MCT detector. Optical adsorption data were collected from 400 to $4000 \mathrm{~cm}^{-1}$ at a resolution of $4 \mathrm{~cm}^{-1}$ and with 128 scans. The $\mathrm{Cu}$-ERI sample $(20 \mathrm{mg})$ was pressed into a selfsupporting disc and activated in the IR cell with 300 torr of oxygen at $400{ }^{\circ} \mathrm{C}$ for $1 \mathrm{~h}$. The system was then evacuated and cooled down prior to measurement. 300 torr of $\mathrm{CH}_{4}$ was then introduced into the cell and reacted with the $\mathrm{Cu}$-ERI sample at $300{ }^{\circ} \mathrm{C}$. Spectra of surface species were obtained by subtracting the reacted sample from the activated $\mathrm{Cu}$-ERI before the reaction with the OMNIC 9.1 software package. For nitrogen monoxide adsorption, the activated sample was cooled to $77 \mathrm{~K}$ with liquid nitrogen. Nitrogen monoxide was dosed into the cell with subsequent acquisition of IR spectrum. The dosing was stopped until the saturation of the sample with NO.

Thermogravimetric and differential thermal analyses (TG-DSC) were performed on a STA $449 \mathrm{C}$ (Jupiter) thermo-microbalance from $30{ }^{\circ} \mathrm{C}$ to $800{ }^{\circ} \mathrm{C}$ at a heating rate of $10^{\circ} \mathrm{C} / \mathrm{min}$ in a flow $(200$ $\mathrm{ml} / \mathrm{min}$ ) of air.

Methane Oxidation Reaction over Cu-ERI Materials. Methane oxidation reaction measurements were carried out in a highpressure reactor. Approximately $300 \mathrm{mg}$ of $\mathrm{Cu}$-ERI material were loaded into a stainless-steel autoclave. The sample was activated in a pure flow of $\mathrm{O}_{2}(25 \mathrm{ml} / \mathrm{min})$ at the target temperature $\left(450{ }^{\circ} \mathrm{C}\right.$ with the conventional method and $300{ }^{\circ} \mathrm{C}$ with the isothermal method) for $1 \mathrm{~h}$. The reactor system was cooled to $300{ }^{\circ} \mathrm{C}$ after activation and purged with a pure helium flow for $20 \mathrm{~min}$. Then, pure methane was fed into the reactor at the same temperature. After the reaction with methane at $300{ }^{\circ} \mathrm{C}$ for $30 \mathrm{~min}$, the reactor was then cooled down to room temperature with a flow of pure helium.
The obtained methanol was extracted offline by adding $2 \mathrm{ml}$ deionized water to the reacted $\mathrm{Cu}$-ERI sample, and the resulting suspension was stirred for $1 \mathrm{~h}$ at room temperature. The aqueous suspension was then filtered and analyzed with a gas chromatograph (Agilent 6890). Butanol was added as the external standard solution. Only one extraction was performed on each $\mathrm{Cu}$-ERI sample for the calculation of methanol yield. In the multiple extraction, the solid sample was collected after the previous extraction and the process was repeated until no more methanol was detected by the gas chromatograph.

\section{RESULTS AND DISCUSSION}

The Cu-ERI samples were prepared by aqueous ion-exchange of the ERI zeolites synthesized using a previously described ultrafast method. ${ }^{[41]} \mathrm{Cu}$-ERI materials with different copper loadings (Table 1) were prepared by varying the concentration of the copper acetate solution used for ion exchange. The $\mathrm{Si} / \mathrm{Al}$ ratio was 5.6 , the $\mathrm{Cu} / \mathrm{Al}$ ratios $0.1,0.2,0.3$ and 0.4 , and the $\mathrm{K} / \mathrm{Al}$ ratio 0.21 in all cases, as measured by AAS analysis. The samples were designated $\mathrm{Cu}$ $\operatorname{ERI}(x)$, where " $x$ " denotes the $\mathrm{Cu} / \mathrm{Al}$ ratio. All the Cu-ERI materials were highly crystalline, as demonstrated by the XRD and nitrogen adsorption-desorption isotherms (Figure S2). The SEM image reveals that the parent ERI zeolite had a particle size of $c a .1 \mu \mathrm{m}$ (Figure S3).
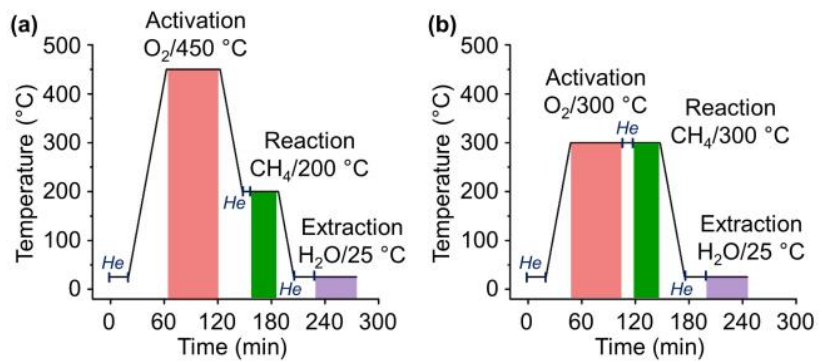

Figure 1. Comparison of (a) the conventional procedure and (b) the isothermal procedure of the stepwise oxidation of methane to methanol with off-line water extraction.

Table 1. Chemical composition of the $\mathrm{Cu}$-ERI materials.

\begin{tabular}{cccccc}
\hline Sample & $\mathrm{Si} / \mathrm{Al}^{\mathrm{b}}$ & ${\mathrm{K} / \mathrm{Al}^{\mathrm{c}}}^{\mathrm{a}}$ & $\mathrm{Cu}^{\mathrm{a}} \mathrm{Al}^{\mathrm{d}}$ & $\begin{array}{c}\mathrm{Cu} \\
(\mathrm{wt} \%)\end{array}$ & $\begin{array}{c}\mathrm{V}_{\text {micro }} \\
\left(\mathrm{cm}^{3} / \mathrm{g}\right)^{\mathrm{e}}\end{array}$ \\
\hline $\mathrm{Cu}-\mathrm{ERI}(0.1)^{\mathrm{a}}$ & 5.6 & 0.21 & 0.1 & 1.6 & 0.19 \\
$\mathrm{Cu}-\mathrm{ERI}(0.2)$ & 5.6 & 0.21 & 0.2 & 3.1 & 0.19 \\
$\mathrm{Cu}-\mathrm{ERI}(0.3)$ & 5.6 & 0.21 & 0.3 & 4.2 & 0.20 \\
$\mathrm{Cu}-\mathrm{ERI}(0.4)$ & 5.6 & 0.21 & 0.4 & 5.9 & 0.19 \\
\hline
\end{tabular}

${ }^{\mathrm{a}} \mathrm{Cu}-\mathrm{ERI}(x), x$ represents $\mathrm{Cu} / \mathrm{Al}$ ratio. ${ }^{\text {bcd }}$ Measured by AAS. ${ }^{\mathrm{e}} \mathrm{Calcu}-$ lated with $t$-plot method.

The performance of the Cu-ERI materials was first evaluated by the conventional procedure (activation at $450{ }^{\circ} \mathrm{C}$ and reaction with methane at $200^{\circ} \mathrm{C}$ ) (Figure 1(a)). Figure 2(a) shows the methanol yields per gram of zeolite obtained over the $\mathrm{Cu}$-ERI materials with different copper loadings. At a methane pressure of 1 bar, $\mathrm{Cu}$-ERI exhibited a nearly linear increase in methanol yield with the copper loading, showing a maximum at about $28 \mu \mathrm{mol} / \mathrm{g}$-zeolite for $\mathrm{Cu}$ ERI(0.4). This result probably suggests that only part of the copper species participated in methane activation under low methane pressure (at $200^{\circ} \mathrm{C}$ ) and that the amount of this type of active sites increased linearly with copper loading. FTIR spectroscopy of adsorbed NO (Figure S4) show that different copper species were present in the activated Cu-ERI samples. The band at 1908 and 1958 $\mathrm{cm}^{-1}$ are believed to be due to copper monomeric species and aggregate copper species (especially dimeric copper), respectively. ${ }^{[25]}$ It seems that copper loading did not alter the nature of copper spe cies in the samples. The density of each type of copper species, however, varied with increasing the copper loading. ${ }^{[24,42]}$ An ele- 

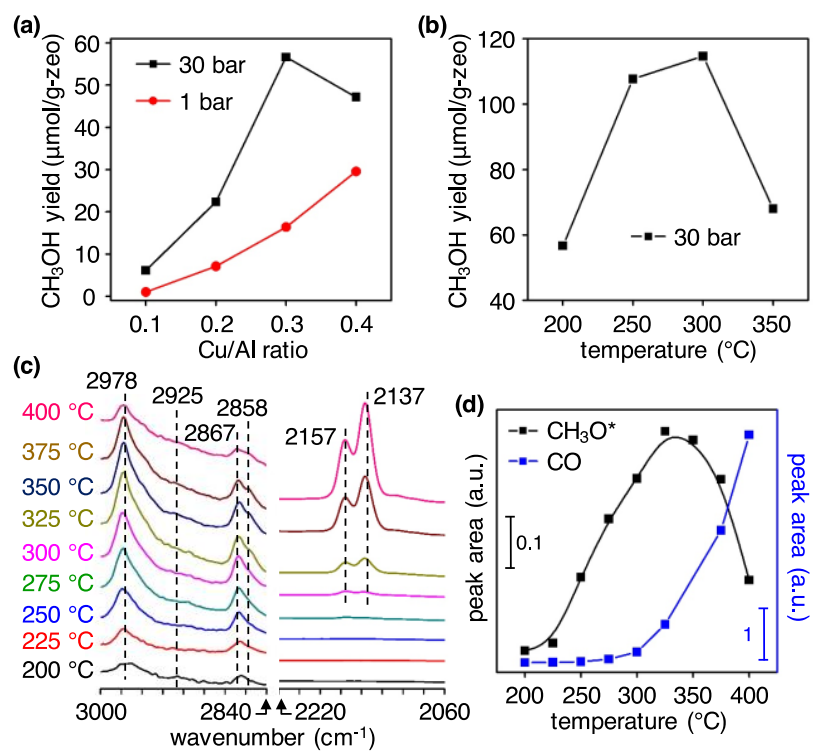

Figure 2. Direct oxidation of methane to methanol over the $\mathrm{Cu}$ ERI zeolites according to the conventional procedure with oxygen activation at $450^{\circ} \mathrm{C}$. (a) Methanol yield of the $\mathrm{Cu}$-ERI zeolites with different copper loadings and different methane partial pressures at $200{ }^{\circ} \mathrm{C}$. (b) Methanol yield of $\mathrm{Cu}$-ERI $(0.3)$ at different reaction temperatures ranging from $200{ }^{\circ} \mathrm{C}$ to $350{ }^{\circ} \mathrm{C}$. (c) In-situ FTIR spectra of surface species formed after the reaction with 300 torr of methane at different temperatures for $30 \mathrm{~min}$. (d) Comparison of the relative intensity of the bands of methoxy species and that of carbon monoxide formed after the reaction with methane at different temperatures for $30 \mathrm{~min}$.

vated methane pressure of 30 bar led to a greater participation of copper species in methane activation, and correspondingly, an enhancement of productivity. In particular, when the copper loading was optimal $(\mathrm{Cu} / \mathrm{Al}=0.3)$, the $\mathrm{Cu}$-ERI gave the highest methanol yield of $56 \mu \mathrm{mol} / \mathrm{g}$-material. The methanol yield normalized by the copper content ( $\mathrm{mol} / \mathrm{mol}$, Figure S5) demonstrated a similar trend. $\mathrm{Cu}$-ERI(0.3) was selected to optimize the methane reaction temperature. Figure 2(b) shows that the methanol productivity doubled (from $56 \mu \mathrm{mol} / \mathrm{g}$ - zeolite to $109 \mu \mathrm{mol} / \mathrm{g}$-zeolite) when the reaction temperature was increased from $200{ }^{\circ} \mathrm{C}$ to $250{ }^{\circ} \mathrm{C}$, and the highest yield of $114 \mu \mathrm{mol} / \mathrm{g}$-zeolite was achieved at $300{ }^{\circ} \mathrm{C}$. A further increase in the reaction temperature to $350^{\circ} \mathrm{C}$ led to a lower methanol yield.

In-situ Fourier-transform infrared spectroscopy (FTIR) was employed to study the surface species formed after the reaction of methane over activated $\mathrm{Cu}$-ERI materials and to understand the effect of the reaction temperature, which strongly affects selectivity and, thus, impacts the methanol yield. ${ }^{[17,30,32,33]}$ Figure 2(c) presents the spectra of surface species formed during the reaction with 300 torr of methane. The bands at $2978 \mathrm{~cm}^{-1}\left(v_{a s} \mathrm{CH}_{3}\right), 2867 \mathrm{~cm}^{-1}\left(v_{s} \mathrm{CH}_{3}\right)$ are assigned to vibrations of methoxy species. The band at 2925 $\mathrm{cm}^{-1}$ and $1598 \mathrm{~cm}^{-1}$ are due to formate species (Figure S6) and those at $2858 \mathrm{~cm}^{-1}$ and $1469 \mathrm{~cm}^{-1}$ (Figure S6) correspond to the methanol formed by the hydrolysis of methoxy species. ${ }^{[22,25,32,43-45]}$ The bands at $2157 \mathrm{~cm}^{-1}$ and $2137 \mathrm{~cm}^{-1}$ are related to the stretching vibrations of carbon monoxide adsorbed at two different $\mathrm{Cu}^{\mathrm{I}}$ sites. The spectra acquired at different temperatures indicate that $\mathrm{Cu}$-ERI displays superior selectivity, because no by-products, such as carbon monoxide and formate (Figure S6), were found up to $300^{\circ} \mathrm{C}$. The intensity of the band attributed to surface methoxy increases with temperature up to $350{ }^{\circ} \mathrm{C}$. From these temperature-dependent observations of product formation, the optimal temperature regime for the operations of $\mathrm{Cu}$-ERI in direct methane conversion to methanol was de-
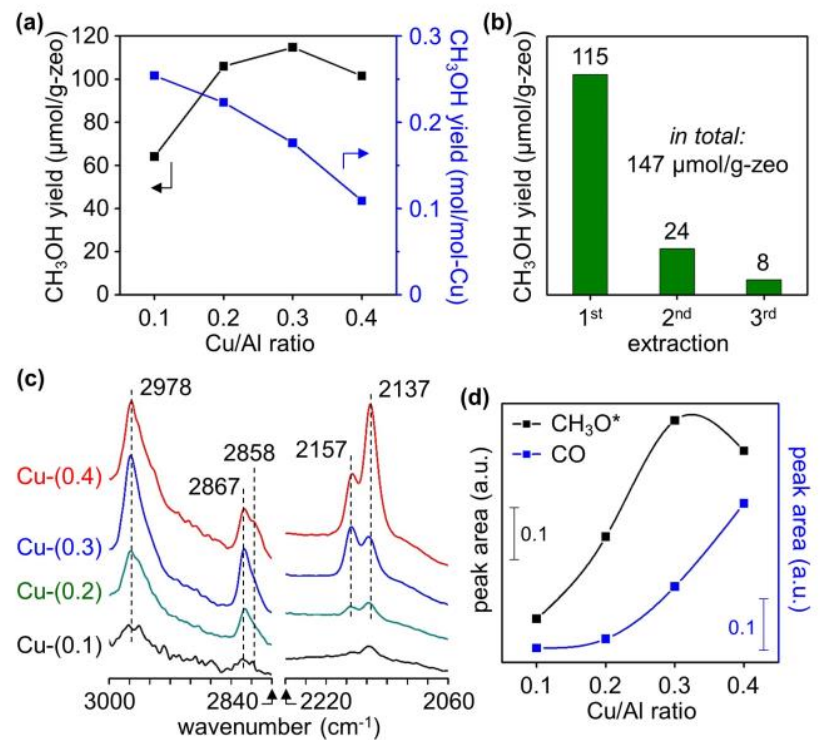

Figure 3. Effect of copper loading on the direct oxidation of methane to methanol over the Cu-ERI zeolites. (a) Methanol yield on the $\mathrm{Cu}$-ERI zeolites with different copper loadings at $300{ }^{\circ} \mathrm{C}$ and methane partial pressure of 30 bar. (b) Multiple methanol extraction performed on the Cu-ERI(0.3) material. (c) In-situ FTIR spectra of surface species formed on the $\mathrm{Cu}$-ERI zeolites with different copper loadings after the reaction with 300 torr of methane for 30 $\min (\mathrm{Cu}-\mathrm{ERI}(x)$ was abbreviated to $\mathrm{Cu}-(x)$ for clarity). (d) Comparison of the relative intensity of the bands of methoxy species and that of carbon monoxide formed on the Cu-ERI zeolites with different copper loadings after the reaction with methane for $30 \mathrm{~min}$.

termined to be around $300{ }^{\circ} \mathrm{C}$ (Figure 2(d)), which is consistent with the reaction results shown in Figure 2(b). The species formed as gas phases in the reaction were also studied by in-situ FTIR to calculate the selectivity over Cu-ERI. As shown in Figure S7, a selectivity of $87 \%$ was achieved after reacting with methane for 30 min at $300{ }^{\circ} \mathrm{C}$. This optimal reaction temperature is $100^{\circ} \mathrm{C}$ higher than that generally reported for other types of zeolites $^{[16,20,24,34,39,40,46]}$, with the exception of copper-exchanged faujasite (Cu-FAU) which also exhibits a high selectivity to methoxy and strong stabilization of these species up to $360{ }^{\circ} \mathrm{C}^{[32]}$. The attainment of high selectivity at these reaction temperatures might be ascribed to the strong stabilization of methoxy species by Brønsted acid sites, which could prevent further oxidation of methoxy species to carbon monoxide, formate, and carbon dioxide. ${ }^{[43]}$ Meanwhile, the confinement within the small-pore structure could likely exert a positive effect, particularly on $\mathrm{C}-\mathrm{H}$ bond cleavage toward methanol formation, and possibly on stabilization of methoxy species and disfavoring over oxidation as well. ${ }^{[34,39,43]}$ These results discussed above further demonstrate the importance of interplay between operation conditions and material properties.

After screening the reaction temperature, the performance of $\mathrm{Cu}$ ERI zeolites with different copper loadings was evaluated at $300^{\circ} \mathrm{C}$ under 30 bar of methane. Figure 3(a) shows that a similar trend of methanol yield per gram zeolite versus copper loading was obtained at $300^{\circ} \mathrm{C}$ as compared with the results at $200{ }^{\circ} \mathrm{C}$. Cu-ERI $(0.3)$ displayed the highest methanol yield of $115 \mu \mathrm{mol} / \mathrm{g}$-zeolite, and a value as high as $147 \mu \mathrm{mol} / \mathrm{g}$-zeolite, equivalent to 0.224 $\mu \mathrm{mol} / \mu \mathrm{mol}-\mathrm{Cu}$, was achieved when three consecutive extractions were carried out (Figure 3(b)). A higher copper loading $(\mathrm{Cu} / \mathrm{Al}=0.4)$ led to a decrease in the methanol yield. In-situ FTIR spectroscopy demonstrated the effect of copper loading on the methanol yield. Figure 3(c) depicts the spectra of surface species formed on $\mathrm{Cu}$ ERI samples with different copper loadings after the reaction with methane at $300{ }^{\circ} \mathrm{C}$. The intensity of the band attributed to carbon 

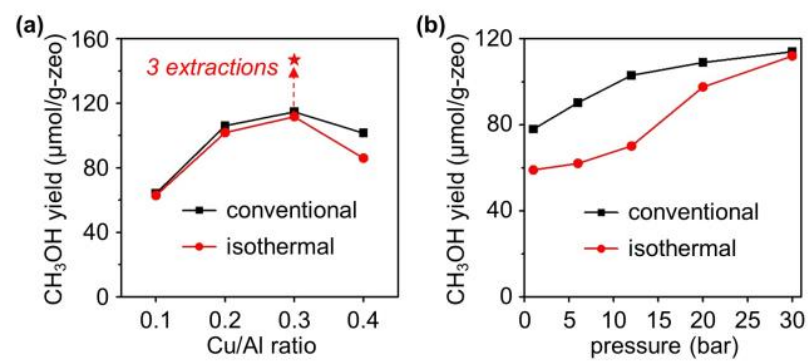

Figure 4. Comparison of the methanol yields obtained over the $\mathrm{Cu}$ ERI zeolites according to the conventional procedure and the isothermal procedure. (a) Methanol yield of the $\mathrm{Cu}$-ERI zeolites with different $\mathrm{Cu}$ loadings after activation at $450{ }^{\circ} \mathrm{C}$ (conventional procedure) and $300{ }^{\circ} \mathrm{C}$ (isothermal procedure. The red asterisk denotes the methanol yield after three extractions). (b) Dependence of methanol yield on methane pressure after activation at $450{ }^{\circ} \mathrm{C}$ (conventional procedure) and $300{ }^{\circ} \mathrm{C}$ (isothermal procedure), respectively.

monoxide increased with copper loading, whereas the intensity of the bands due to surface methoxy species reached its maximum at $\mathrm{Cu}-\mathrm{ERI}(0.3)$ and decreased for $\mathrm{Cu}-\mathrm{ERI}(0.4)$. This result indicates that increasing the copper loading does not necessarily lead to an increase in the methanol yield; there is a critical copper loading, which, when exceeded, lowers selectivity to methanol due to overoxidation (Figure 3(d)).

The fact that a relatively high methane reaction temperature can be applied to the $\mathrm{Cu}$-ERI suggests the feasibility of establishing an isothermal operation regime, similar to that shown for $\mathrm{Cu}-\mathrm{FAU} .^{[32]}$ Figure 4(a) presents the methanol yields obtained with the conventional procedure (Figure 1(a)) and those with the isothermal procedure (Figure 1(b)). All Cu-ERI materials with different copper loadings achieved a high methanol yield in the isothermal approach, which was comparable to the yield obtained in the conventional approach. According to previous studies, pretreatment at a high temperature above $450{ }^{\circ} \mathrm{C}$ is a prerequisite to producing the maximum concentration of active sites. ${ }^{[33,34,46]}$ Activation at lower temperatures reduces the yield of methanol, probably as a result of the incomplete removal of water. ${ }^{[17]}$ However, as demonstrated by the TG-DTA (Figure S8), Cu-ERI is almost completely dehydrated at $300{ }^{\circ} \mathrm{C}$; thus, there is no reason to perform activation at higher temperatures with this zeolite. The methanol yield obtained at $30 \mathrm{bar}$ of methane is the same for both activation procedures (Figure 4 (a)). The effect of methane partial pressure on the methanol productivity was investigated by means of two different procedures. The plots in Figure 4(b) demonstrate that elevating the methane pressure increased the production of methanol in both procedures. A similar trend was observed on the MOR, MAZ and CHA zeolites, where an increase in the methane partial pressure was shown to increase the fraction of copper active species that participate in $\mathrm{C}-\mathrm{H}$ cleavage..$^{[33,40,47]}$ After high-temperature oxygen activation at $450{ }^{\circ} \mathrm{C}$, the methanol yield was almost saturated at 15 bar of methane (Figure 4(b)), while in the isothermal procedure, a higher methane pressures are required to produce the maximum amount of methanol. This might be associated with the small amount of water retained in the zeolite after activation at $300{ }^{\circ} \mathrm{C}$ (Figure S8). However, the yield is only slightly lower than in the conventional procedure, indicating that high-temperature activation in oxygen is not a prerequisite for the conversion of methane to methanol in the Cu-ERI system. From a practical perspective, the decrease in activation temperature is attractive, as it enables isothermal methane partial oxidation at $300{ }^{\circ} \mathrm{C}$ and, thus, would facilitates the process design. ${ }^{[32,48]}$ Furthermore, a multicycle experiment performed over Cu-ERI $(0.3)$ with off-line extraction at room temperature showed a stable meth- anol yield of $113 \pm 2 \mu \mathrm{mol} / \mathrm{g}$-zeolite over four reactive cycles (Figure S9), which is probably attributable to the high hydrothermal stability of the Cu-ERI zeolite. ${ }^{[41]}$ XRD patterns (Figure S10) and TEM images (Figure S11) of the Cu-ERI(0.3) before and after methane oxidation confirm that the zeolite structure was maintained and that no (XRD visible) copper oxide particles formed.

\section{CONCLUSIONS}

In summary, the $\mathrm{Cu}$-ERI zeolite exhibits excellent performance in the direct oxidation of methane to methanol, and a high selectivity was observed even at a relatively high methane reaction temperature of $300{ }^{\circ} \mathrm{C}$, which is $100{ }^{\circ} \mathrm{C}$ higher than the optimal reaction temperature for most of the copper-containing zeolites. With an optimized copper loading and under elevated methane partial pressure, $\mathrm{Cu}$-ERI led to a methanol yield of as high as $147 \mu \mathrm{mol} / \mathrm{g}$-zeolite at 30 bar of methane under conventional conditions. Thanks to its high activity and selectivity at $300{ }^{\circ} \mathrm{C}$, an equivalently high methanol yield was achieved by means of the isothermal procedure with both oxygen activation and reaction with methane carried out at $300{ }^{\circ} \mathrm{C}$. Due to its high hydrothermal stability, Cu-ERI zeolite exhibited a stable methanol yield of $113 \pm 2 \mu \mathrm{mol} / \mathrm{g}$-zeolite per cycle. These results reveal that the Cu-ERI zeolite has the potential to emerge as a competitive material in the direct oxidation of methane to methanol. Further studies focusing on ERI samples with a variety of properties (e.g. different $\mathrm{Si} / \mathrm{Al}$ ratios, cations and morphologies) are ongoing, which will help reveal the structure-performance relationship of $\mathrm{Cu}$-ERI zeolites and explore a more feasible protocol to achieve a high methanol yield over this small-pore zeolite.

\section{ASSOCIATED CONTENT}

\section{Supporting Information}

The Supporting Information is available free of charge on the ACS Publications website.

Characteristics of the $\mathrm{Cu}$-ERI materials revealed XRD patterns, SEM images and nitrogen adsorption-desorption isotherm. In-situ FTIR spectra of species formed during the reaction with methane.

\section{AUTHOR INFORMATION}

\section{Corresponding Author}

*E-mail: jeroen.vanbokhoven@chem.ethz.ch (J. A. van B.) liuzd@chemsys.t.u-tokyo.ac.jp (Z. L.)

\section{Author Contributions}

The manuscript was written through contributions of all authors. All authors have given approval to the final version of the manuscript.

Notes

There are no conflicts of interest to declare.

\section{ACKNOWLEDGMENT}

Dr. Frank Krumeich is acknowledged for support in SEM observation. J. Z. thanks Japan Society for the Promotion of Science (JSPS Research Fellowship for Young Scientists: 18J22185) and the Program for Leading Graduate Schools, "Global Leader Pro-gram for Social Design and Management (GSDM)", by MEXT for financial support.

\section{REFERENCES}

(1) Nisbet, E. G.; Dlugokencky, E. J.; Bousquet, P. Methane on the Rise-Again. Science 2014, 343, 493-495.

(2) Ren, T.; Patel, M.; Blok, K. Olefins from Conventional and Heavy Feedstocks: Energy Use in Steam Cracking and Alternative Processes. Energy 2006, 31, 425-451. 
(3) Hammond, C.; Conrad, S.; Hermans, I. Oxidative Methane Upgrading. ChemSusChem 2012, 5, 1668-1686.

(4) Gesser, H. D.; Hunter, N. R.; Prakash, C. B. The direct Conversion of Methane to Methanol by Controlled Oxidation. Chem. Rev. 1985, 85, 235-244.

(5) Foster, N. R. Direct Catalytic Oxidation of Methane to Methanol-a review. Appl. Catal. 1985, 19, 1-11.

(6) Periana, R.; Taube, D.; Gamble, S.; Taube, H.; Satoh, T.; Fujii, H. Platinum Catalysts for the High-Yield Oxidation of Methane to a Methanol Derivative. Science 1998, 280, 560-564. (7) Crabtree, R. H. Aspects of Methane Chemistry. Chem. Rev. 1995, 95, 987-1007.

(8) Ravi, M.; Sushkevich, V. L.; Knorpp, A. J.; Newton, M. A.; Palagin, D.; Pinar, A. B.; Ranocchiari, M.; van Bokhoven, J. A. Misconceptions and Challenges in Methane-to-Methanol over Transition-Metal-Exchanged zeolites. Nat. Catal. 2019, 2, 485494.

(9) Lange, J.-P.; de Jong, K. P.; Ansorge, J.; Tijm, P. J. A. Keys to Methane Conversion Technologies. Stud. Surf. Sci. Catal. 1997, 107, 81-86.

(10) Ahlquist, M.; Nielsen, R. J.; Periana, R. A.; Goddard III, W. A. Product Protection, the Key to Developing High Performance Methane Selective Oxidation Catalysts. J. Am. Chem. Soc. 2009, 131, 17110-17115.

(11) Ravi, M.; Ranocchiari, M.; van Bokhoven, J. A. The Direct Catalytic Oxidation of Methane to Methanol-A Critical Assessment. Angew. Chem. Int. Ed. 2017, 56, 16464-16483.

(12) Yoshizawa, K.; Shiota, Y. Conversion of Methane to Methanol at the Mononuclear and Dinuclear Copper Sites of Particulate Methane Monooxygenase (pMMO): A DFT and QM/MM Study. J. Am. Chem. Soc. 2006, 128, 9873-9881.

(13) Groothaert, M. H.; Smeets, P. J.; Sels, B. F.; Jacobs, P. A.; Schoonheydt, R. A. Selective Oxidation of Methane by the Bis( $\mu$-oxo)dicopper Core Stabilized on ZSM-5 and Mordenite Zeolites. J. Am. Chem. Soc. 2005, 127, 1394-1395.

(14) Knorpp, A. J.; Newton, M. A.; Pinar, A. B.; van Bokhoven, J. A. Conversion of Methane to Methanol on Copper Mordenite: Redox Mechanism of Isothermal and High-Temperature-Activation Procedures. Ind. Eng. Chem. Res. 2018, 57, 12036-12039.

(15) Woertink, J. S.; Smeets, P. J.; Groothaert, M. H.; Vance, M. A.; Sels, B. F.; Schoonheydt, R. A.; Solomon, E. I. A $\left[\mathrm{Cu}_{2} \mathrm{O}\right]^{2+}$ core in $\mathrm{Cu}-\mathrm{ZSM}-5$, the active site in the oxidation of methane to methanol. Proc Natl Acad Sci US A. 2009, 106, 18908-18913.

(16) Alayon, E. M. C.; Nachtegaal, M.; Ranocchiari, M.; van Bokhoven, J. A. Catalytic Conversion of Methane to Methanol over $\mathrm{Cu}-\mathrm{Mordenite.} \mathrm{Chem.} \mathrm{Commun.} \mathrm{2012,} \mathrm{48,} \mathrm{404-406.}$

(17) Alayon, E. M. C.; Nachtegaal, M.; Bodi, A.; van Bokhoven, J. A. Reaction Conditions of Methane-to-Methanol Conversion Affect the Structure of Active Copper Sites. ACS Catal. 2014, $4,16-22$.

(18) Vanelderen, P.; Snyder, B. E. R.; Tsai, M.-L.; Hadt, R. G.; Vancauwenbergh, J.; Coussens, O.; Schoonheydt, R. A.; Sels, B. F.; Solomon, E. I. Spectroscopic Definition of the Copper Active Sites in Mordenite: Selective Methane Oxidation. J. Am. Chem. Soc. 2015, 137, 6383-6392.

(19) Bozbag, S. E.; Alayon, E. M. C.; Pechacek, J.; Nachtegaal, M.; Ranocchiari, M.; van Bokhoven, J. A. Methane to Methanol over Copper Mordenite: Yield Improvement through Multiple Cycles and Different Synthesis Techniques. Catal. Sci. Technol. 2016, 6, 5011-5022.
(20) Grundner, S.; Luo, W.; Sanchez-Sanchez, M.; Lercher, J. A. Synthesis of single-site copper catalysts for methane partial oxidation. Chem. Commun. 2016, 52, 2553-2556.

(21) Tomkins, P.; Ranocchiari, M.; van Bokhoven, J. A. Direct Conversion of Methane to Methanol under Mild Conditions over $\mathrm{Cu}$-Zeolites and beyond. Acc. Chem. Res. 2017, 50, 418425.

(22) Sushkevich, V. L.; Palagin, D.; Ranocchiari, M.; van Bokhoven, J. A. Selective anaerobic oxidation of methane enables direct synthesis of methanol. Science 2017, 356, 523-527. (23) Kim, Y.; Kim, T. Y.; Lee, H.; Yi, J. Distinct Activation of $\mathrm{Cu}-\mathrm{MOR}$ for Direct Oxidation of Methane to Methanol. Chem. Commun. 2017, 53, 4116-4119.

(24) Pappas, D. K.; Martini, A.; Dyballa, M.; Kvande, K.; Teketel, S.; Lomachenko, K. A.; Baran, R.; Glatzel, P.; Arstad, B.; Berlier, G.; Lamberti, C.; Bordiga, S.; Olsbye, U.; Svelle, S.; Beato, P.; Borfecchia, E. The Nuclearity of the Active Site for Methane to Methanol Conversion in $\mathrm{Cu}$-Mordenite: A Quantitative Assessment. J. Am. Chem. Soc. 2018, 140, 1527015278.

(25) Sushkevich, V. L.; Palagin, D.; van Bokhoven, J. A. The Effect of the Active-Site Structure on the Activity of Copper Mordenite in the Aerobic and Anaerobic Conversion of Methane into Methanol. Angew. Chem. Int. Ed. 2018, 57, 89068910.

(26) Kulkarni, A. R.; Zhao, Z.; Siahrostami, S.; Nørskovab, J. K.; Studt, F. Cation-Exchanged Zeolites for the Selective Oxidation of Methane to Methanol. Catal. Sci. Technol. 2018, 8, 114-123.

(27) Smeets, P. J.; Hadt, R. G.; Woertink, J. S.; Vanelderen, P.; Schoonheydt, R. A.; Sels B. F.; Solomon, E. I. Oxygen Precursor to the Reactive Intermediate in Methanol Synthesis by $\mathrm{Cu}$ ZSM-5. J. Am. Chem. Soc. 2010, 132, 14736-14738.

(28) Tsai, M. L.; Hadt, R. G.; Vanelderen, P.; Sels, B. F.; Schoonheydt R. A.; Solomon, E. I. $\left[\mathrm{Cu}_{2} \mathrm{O}\right]^{2+}$ Active Site Formation in $\mathrm{Cu}-\mathrm{ZSM}-5$ : Geometric and Electronic Structure Requirements for $\mathrm{N}_{2} \mathrm{O}$ Activation. J. Am. Chem. Soc. 2014, 136, 3522-3529.

(29) Mahyuddin, M. H.; Staykov, A.; Shiota, Y.; Yoshizawa, K. Direct Conversion of Methane to Methanol by Metal-Exchanged ZSM-5 Zeolite (Metal = Fe, Co, Ni, Cu). ACS Catal . 2016, 6, 8321-8331.

(30) Sheppard, T.; Daly, H.; Goguet, A.; Thompson, J. M. Improved Efficiency for Partial Oxidation of Methane by Controlled Copper Deposition on Surface-Modified ZSM-5. ChemCatChem. 2016, 8, 562-570.

(31) Smeets, P. J.; Groothaert M. H.; Schoonheydt, R. A. Cu Based Zeolites: A UV-vis Study of the Active Site in the Selective Methane Oxidation at Low Temperatures. Catal. Today 2005, 110, 303-309.

(32) Sushkevich, V. L.; van Bokhoven, J. A. Methane-to-Methanol: Activity Descriptors in Copper-Exchanged Zeolites for the Rational Design of Materials. ACS Catal. 2019, 9, 62936304.

(33) Pappas, D. K.; Borfecchia, E.; Dyballa, M.; Pankin, I. A.; Lomachenko, K. A.; Martini, A.; Signorile, M.; Teketel, S.; Arstad, B.; Berlier, G.; Lamberti, C.; Bordiga, S.; Olsbye, U.; Lillerud, K. P.; Svelle, S.; Beato, P. Methane to Methanol: Structure-Activity Relationships for Cu-CHA. J. Am. Chem. Soc. 2017, 139, 14961-14975.

(34) Wulfers, M. J.; Teketel, S.; Ipeka, B.; Lobo, R. F. Conversion of Methane to Methanol on Copper-Containing Small-Pore Zeolites and Zeotypes. Chem. Commun. 2015, 51, 4447-4450. 
(35) Knorpp, A. J.; Pinar, A. B.; Newton, M.; Sushkevich, V. L.; van Bokhoven, J. A. Copper-Exchanged Omega (MAZ) Zeolite: Copper-concentration Dependent Active Sites and its Unprecedented Methane to Methanol Conversion. ChemCatChem. 2018, 10, 5593-5596.

(36) Bozbag, S. E.; Sot, P.; Nachtegaal, M.; Ranocchiari, M.; van Bokhoven J. A.; Mesters, C. Direct Stepwise Oxidation of Methane to Methanol over $\mathrm{Cu}-\mathrm{SiO}_{2}$. ACS Catal. 2018, 8, 57215731 .

(37) Le, H. V.; Parishan, S.; Sagaltchik, A.; Ahi, H.; Trunschke, A.; Schomäcker, R.; Thomas, A. Stepwise Methane-to-Methanol Conversion on CuO/SBA-15. Chem. Eur. J. 2018, 24, 12592-12599.

(38) Meyet, J.; Searles, K.; Newton, M. A.; Wörle, M.; van Bavel, A. P.; Horton, A. D.; van Bokhoven, J. A.; Copéret, C. Monomeric Copper(II) Sites Supported on Alumina Selectively Convert Methane to Methanol. Angew. Chem. Int. Ed., 2019, 131, 9946-9950.

(39) Park, M. B.; Ahn, S. H.; Mansouri, A.; Ranocchiari, M.; van Bokhoven, J. A. Comparative Study of Diverse Copper Zeolites for the Conversion of Methane into Methanol. ChemCatChem. 2017, 9, 3705-3713.

(40) Tomkins, P.; Mansouri, A.; Bozbag, S. E.; Krumeich, F.; Park, M. B.; Alayon, E. M. C.; Ranocchiari, M.; van Bokhoven, J. A. Isothermal Cyclic Conversion of Methane into Methanol over Copper-Exchanged Zeolite at Low Temperature. Angew. Chem. Int. Ed. 2016, 55, 5467-5471.

(41) Zhu, J.; Liu, Z.; Iyoki, K.; Anand, C.; Yoshida, K.; Sasaki, Y.; Sukenaga, S.; Ando, M.; Shibata, H.; Okubo, T.; Wakihara, T. Ultrafast Synthesis of High-Silica Erionite Zeolites with Improved Hydrothermal Stability. Chem. Commun. 2017, 53, 6796-6799.

(42) Paolucci, C.; Khurana, I.; Parekh, A. A.; Li, S.; Shih, A. J.; Li, H.; Iorio, J. R. D.; Albarracin-Caballero, J. D.; Yezerets, A.; Miller, J. T.; Delgass, W. N.; Ribeiro, F. H.; Schneider1,W. F.; Gounder, R. Dynamic Multinuclear Sites Formed by Mobilized Copper Ions in $\mathrm{NO}_{\mathrm{x}}$ Selective Catalytic Reduction. Science 2017, 357, 898-903.

(43) Sushkevich, V. L.; van Bokhoven, J. A. Effect of Brønsted Acid Sites on the Direct Conversion of Methane into Methanol over Copper-Exchanged Mordenite. Catal. Sci. Technol. 2018, $8,4141-4150$.

(44) Borfecchia, E.; Lomachenko, K. A.; Giordanino, F.; Falsig, H.; Beato, P.; Soldatov, A. V.; Bordiga, S.; Lamberti, C. Chem. Sci. 2015, 6, 548-563.

(45) Bordiga, S.; Lamberti, C.; Bonino, F.; Travert, A.; Thibault-Starzyk, F. Probing Zeolites by Vibrational Spectroscopies. Chem. Soc. Rev. 2015, 44, 7262-7341.

(46) Ikuno, T.; Grundner, S.; Jentys, A.; Li, G.; Pidko, E.; Fulton, J.; Sanchez-Sanchez, M.; Lercher, J. A. Formation of Active $\mathrm{Cu}$-oxo Clusters for Methane Oxidation in $\mathrm{Cu}$-Exchanged Mordenite. J. Phys. Chem. C 2019, 123, 8759-8769.

(47) Knorpp, A. J.; Newton, M. A.; Mizuno, S. C. M.; Zhu, J.; Mebrate, H.; Pinar, A. B.; van Bokhoven, J. A. Comparative performance of $\mathrm{Cu}$-zeolites in the isothermal conversion of methane to methanol. Chem. Comm. 2019, 55, 11794-11797.

(48) Lange, J.-P.; Sushkevich, V. L.; Knorpp, A. J.; van Bokhoven, J. A. Methane-to-Methanol via Chemical Looping: Economic Potential and Guidance for Future Research. Ind. Eng. Chem. Res. 2019, 58, 8674-8680. 
$\mathrm{Cu}$-Erionite achieves a high methanol yield $(147 \mu \mathrm{mol} / \mathrm{mol} / \mathrm{g}$-zeolite, or $0.224 \mu \mathrm{mol} / \mu \mathrm{mol}-\mathrm{Cu})$ in an isothermal chemical looping with both the oxygen activation and methane reaction carried out at $300{ }^{\circ} \mathrm{C}$, which is comparable to the yield obtained in the conventional approach requiring high-temperature oxygen activation.

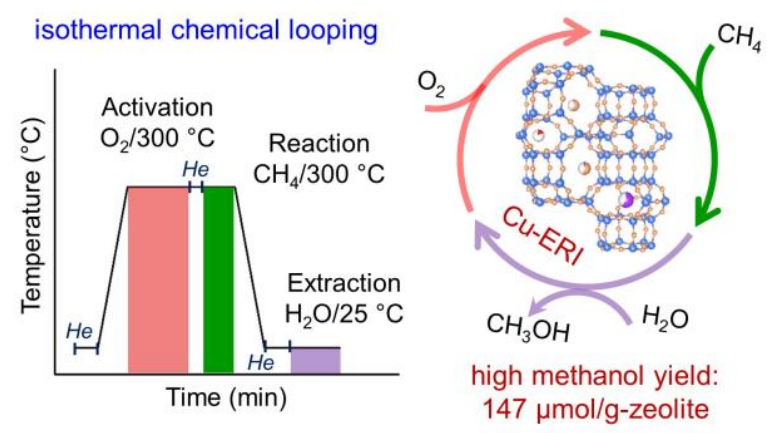

